\title{
A Review of Technological and Vocational Education Upgraded in Taiwan based on Risk Management, Insurance and Finance Education
}

\author{
Li-Ann Huang \\ Chung Chou University of Science and Technology \\ E-Mail: annn@dragon.ccut.edu.tw \\ Li-Hua Lai \\ National Kaohsiung First University of Science and Technology \\ E-Mail: lihua@ccms.nkfust.edu.tw
}

\begin{abstract}
It is a fact that the rapid growth of technological and vocational education in Taiwan is causing a significant structural change in higher education. The main objective of this paper is to study the upgraded effects that affect the planning for the RMI-related departments in the technological and vocational education. Using paired-samples T test, ANOVA and regression method, the effects from junior college upgraded to technological college issues are empirically analyze to investigate the factors from upgraded. Our results show that the decrease of student numbers isn't significance, and the increase of the RMI course numbers, departments and teacher numbers were significant when junior colleges upgraded to technological colleges. These results also provide that the RMI courses are positively associated with the upgrade, student numbers and department numbers, and negatively related with teacher numbers. The result of this is that the change risk of technological and vocational education has become an important factor in reform and developing of Taiwan's higher education.
\end{abstract}

Keywords: Technological and Vocational Education, Risk Management Education 


\section{INTRODUCTION}

Human capital is acknowledged to be a highly productive resource and in the "knowledge-based" economy of the late twentieth century. Colleges and universities have an effect on the availability of labor in their local area in a variety of ways. Note that business education can be judged based on four categories: knowledge, which allows students to understand; know-how, which allows students to put their knowledge to work; wisdom, which enables them to decide whether, where, or when to do it; character, which makes them decent human beings fit to live nearby (Gill A, Lashine S, 2003). The rapid growth of higher technological and vocational education in Taiwan is causing a significant structural change in higher education. Technological and vocational of higher education in Taiwan comprises junior colleges, technological colleges and technological university. The purpose of higher technological and vocational education is to meet the needs of the economy development (Pisut, 1993; Law, 1995; Mok, 2000; Doyon, 2001; Itoh, 2002). The children in Taiwan are declining, for the reason junior colleges no longer have enough students. In order to have enough student sources and increase the quality of school service, junior colleges in Taiwan extensive upgraded into technological colleges. A first-rate curriculum plus good job opportunities will attract more students into risk management and insurance department discipline (Skipper, Harold D. Jr, 1994).

Quality of risk management and insurance education must arise to meet the need of economy. For the reason, the risk management and insurance education programs of junior colleges upgraded to technological colleges are important. Technological and vocational education upgraded events have brought drastic impacts upon courses change in risk management education. The purpose of the project is to gauge the status of upgraded collegiate risk management and insurance education and observe trends in course offerings. The article discusses these influences factors of change in risk management education. The study finds that four factors have served to change the courses of risk management education. The analysis also points to higher technological and vocational education upgraded in Taiwan. This paper organized as follows. Section 2 describes the status of higher technological and vocational education upgraded and the statue of risk management and insurance education in Taiwan. Section 3 describes the methodology concerning the effect factors of RMI course numbers of the regression model. Section 4 describes the result concerning to get the variations of risk management and insurance course numbers of departments of finance and insurance between junior colleges and technological colleges. General discussion and conclude the paper in Section 5. 


\section{LITERATURE REVIEW}

\section{Higher Technological and Vocational Education Upgraded in Taiwan}

The past century has bee tremendous expansion of higher education around the world (Brown and Lauder, 1996; Banks, 2001; Jones, 1998; Schofer and Meyer, 2005; Mongkhonvanit, 2003). Education expands not because a particular society democratizes, but because of global trends regarding democracy and human rights (Schofer and Meyer, 2005). In Taiwan, the changes of higher technological and vocational education upgraded affected from the relevant laws of higher education. Such as "implementation regulations governing the reorganization of junior colleges into technical colleges and the establishment of junior college divisions by technical colleges and technical universities" and "procedural regulations for reviewing plans by junior colleges to reorganize into technical colleges and establish junior college divisions" were announced in 1996. Higher education is a very important means of social and ideological control, been tightly monitored by the government (Law, 1998). The capacity of institutional was not devolved to individual higher education institutions before the political reforms initiated in the late 1980s in Taiwan. Therefore, Taiwan's higher education structure was been changes since the late 1980s, and more higher education institutions have successively formed until 2006, the number of higher education schools jumped to 163 (MOE of Taiwan, 2007) which more than half of them were universities shown in Table 1 (Lai and Huang, 2008).

To meet the changing of global finance, the higher education of risk management and insurance departments upgraded from junior college to technological college, to supply the human resource of risk management and insurance (Thrower and Diana, 1989; Thrower and Gardner, 1989). Due to junior colleges upgraded to technological colleges and some technological colleges change into technological universities, that technological college decline after 2003. The numbers of junior college, technological college and university of technology change as Figure 1. The number of junior college schools decline to 16 and technological college schools increase to 45 and technological university increase to 32 during 1986 through 2006 (MOE of Taiwan 2007; Lai and Huang, 2007; Lai and Huang, 2008). In practice, some dramatic discipline-specific changes appear to be influencing RMI education (Dorfman 1990; Gardner and Schmit, 1995). We can see that most schools house their RMI courses in risk management and insurance, finance or business administration departments, and many use expansion to staff their RMI courses (Cummins, 1987; Gardner and Schmit, 1995 ) for departments increased after upgraded. In Taiwan, we find little phenomenon 
that the number of schools offering RMI courses and departments upgraded have increased in recent years. These results will that the number of schools with RMI courses have relatively changes after upgraded. Whether a school offers RMI courses depends on its upgraded condition, the numbers of teacher, student and related department. Therefore, considerations should be given to the evaluated between the educational backgrounds of graduating RMI courses after junior colleges have upgraded to technological colleges.

Table 1 Develop in Higher Education of School Year (1986-2006)

\begin{tabular}{|c|c|c|c|c|c|c|c|c|c|}
\hline $\begin{array}{l}\text { School } \\
\text { Year }\end{array}$ & $\begin{array}{l}\text { Number } \\
\text { of higher } \\
\text { education } \\
\text { schools }\end{array}$ & University & College & $\begin{array}{l}\text { Junior } \\
\text { College }\end{array}$ & $\begin{array}{c}\text { Number of } \\
\text { Technological } \\
\text { University and } \\
\text { College }\end{array}$ & $\begin{array}{c}\text { Technological } \\
\text { University }\end{array}$ & $\begin{array}{c}\text { Technological } \\
\text { College }\end{array}$ & $\begin{array}{c}\text { Regular } \\
\text { University }\end{array}$ & $\begin{array}{c}\text { Technological } \\
\text { and Vocational } \\
\text { Schools of } \\
\text { Higher } \\
\text { Education }\end{array}$ \\
\hline 1986 & 105 & 16 & 12 & 77 & 1 & 0 & 1 & 27 & 78 \\
\hline 1987 & 107 & 16 & 23 & 68 & 1 & 0 & 1 & 38 & 69 \\
\hline 1988 & 109 & 16 & 23 & 70 & 1 & 0 & 1 & 38 & 71 \\
\hline 1989 & 116 & 21 & 20 & 75 & 1 & 0 & 1 & 40 & 76 \\
\hline 1990 & 121 & 21 & 25 & 75 & 1 & 0 & 1 & 45 & 76 \\
\hline 1991 & 123 & 21 & 29 & 73 & 3 & 0 & 3 & 47 & 76 \\
\hline 1992 & 124 & 21 & 29 & 74 & 3 & 0 & 3 & 47 & 77 \\
\hline 1993 & 125 & 21 & 30 & 74 & 3 & 0 & 3 & 48 & 77 \\
\hline 1994 & 130 & 23 & 35 & 72 & 6 & 0 & 6 & 52 & 78 \\
\hline 1995 & 134 & 24 & 36 & 74 & 7 & 0 & 7 & 53 & 81 \\
\hline 1996 & 137 & 24 & 43 & 70 & 10 & 0 & 10 & 57 & 80 \\
\hline 1997 & 139 & 38 & 40 & 61 & 20 & 5 & 15 & 58 & 81 \\
\hline 1998 & 137 & 39 & 45 & 53 & 26 & 6 & 20 & 58 & 79 \\
\hline 1999 & 141 & 44 & 61 & 36 & 47 & 7 & 40 & 58 & 83 \\
\hline 2000 & 150 & 53 & 74 & 23 & 62 & 11 & 51 & 65 & 85 \\
\hline 2001 & 154 & 57 & 78 & 19 & 67 & 12 & 55 & 68 & 86 \\
\hline 2002 & 154 & 61 & 78 & 15 & 71 & 15 & 56 & 68 & 86 \\
\hline 2003 & 158 & 70 & 73 & 15 & 73 & 20 & 53 & 70 & 88 \\
\hline 2004 & 159 & 75 & 70 & 14 & 75 & 22 & 53 & 70 & 89 \\
\hline 2005 & 162 & 89 & 56 & 17 & 75 & 29 & 46 & 70 & 92 \\
\hline 2006 & 163 & 94 & 53 & 16 & 77 & 32 & 45 & 70 & 93 \\
\hline
\end{tabular}




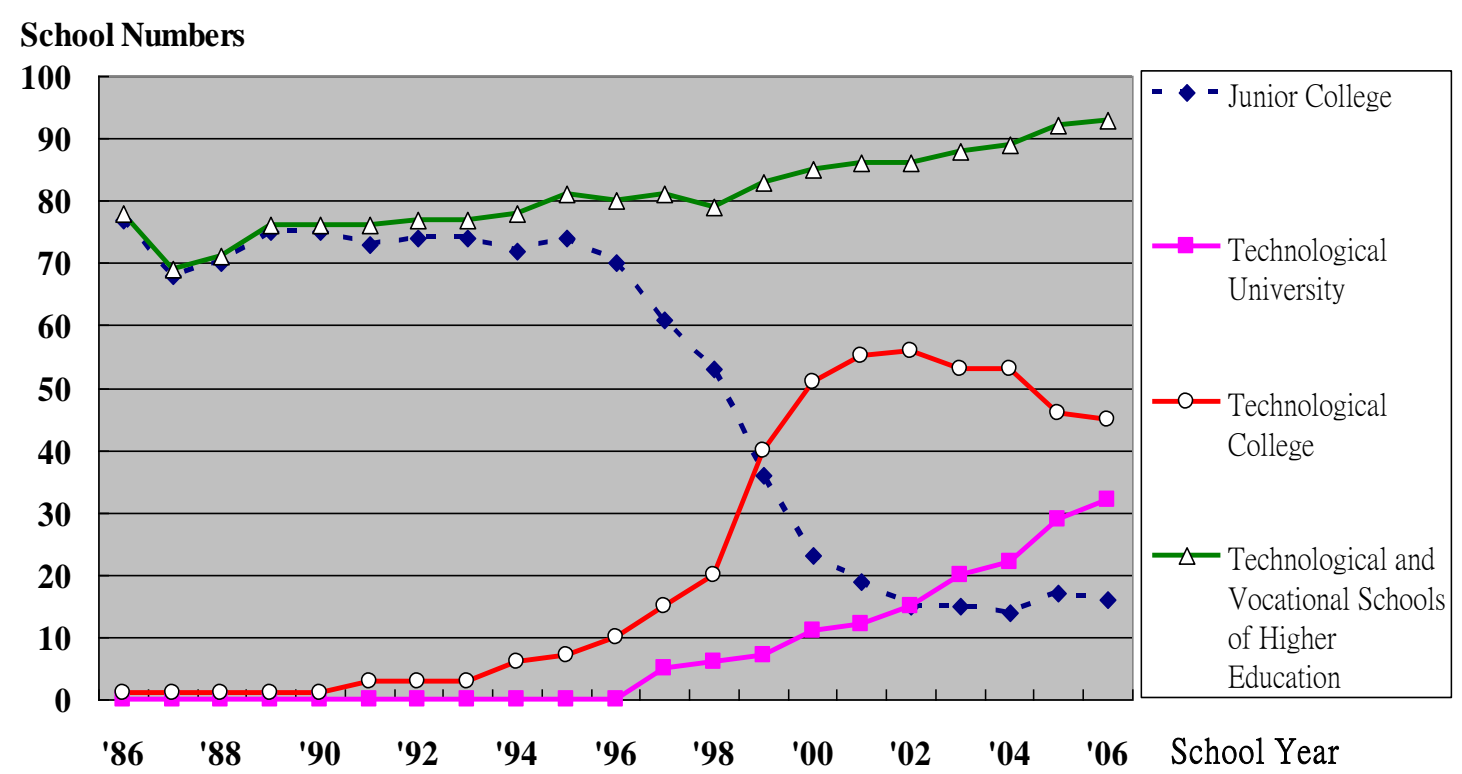

Figure 1 Higher Education of Technological and Vocational Upgraded in Taiwan

\section{Statues of Risk Management and Insurance Education in Taiwan}

This paper shows that the student numbers are all in department of risk management, insurance and finance. Figure 2 shows that the numbers of teacher, departments and RMI course numbers are increase which the teacher numbers and RMI courses shall increase as the number of insurance and finance department increased (Lai and Huang, 2008). When the department number increased, they need to hire more teachers and offer more RMI courses. But the student number presents decline as junior colleges upgraded to technological colleges. Note that this result may be cause by the Ministry of Education to adopt the project of total amount controlling and class number reduced.

In Figure 3 in order to compete and to establish a distinguishing feature, RMI course numbers of finance and insurance departments of every junior college upgraded to technological college were almost raise.

\section{Influence Factors of Course Offering}

One of the university functions is to provide adequate and qualified human resources during the national economic development (Yang, 1995, Lin, Chang, 1998) and the resources coming from the government, universities, enterprises and research institutions have to be integrated with a view to promoting the economic development (Huang, 2000). Accordingly, the departments in universities have to adjust themselves to meet the human resource demands of industries in the fast changing world. The 
curriculum was becoming profesionalized (Meyer, Kamens, Benavot, Cha, \& Wong, 1992), determined by professionals, elites, and social scientists instead of solely by local politicians or interest groups.

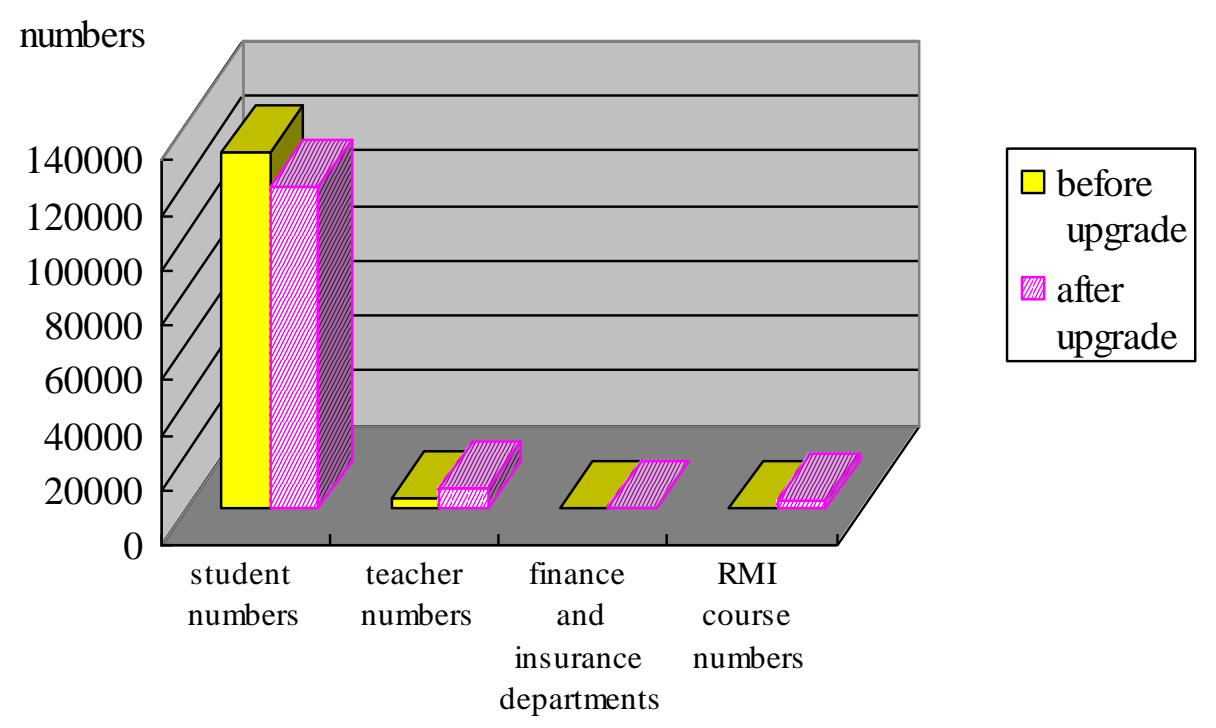

Figure 2 Numbers of Insurance and Finance Departments, RMI Courses, Students and Teachers Change from Junior Colleges Upgraded to Technological Colleges

Students in large schools may have more flexibility in selecting courses than students in small schools (Barker, 1985). Larger schools, due to larger enrollments and resources, may offer more varied course offerings. By providing more varied course offerings, students have greater flexibility in choosing courses to fulfill their graduation requirements and future career objectives. It would seem that large schools do have an edge. There is a tendency for the number of course offerings to increase as the size of the high school increases (Wiles, 1995). Large schools consistently offered more advanced courses than small or medium high schools (Melnick, et. al., 1987).

\section{MODEL AND METHODOLOGY}

\section{Frame of Research}

This paper aims at discussing risk management education of higher education of technological and vocational schools upgraded and observe differences on RMI course numbers, teacher numbers, student numbers and department of insurance and finance between before upgrade and after upgrade. On the other hand, this paper aims at 
discussing the effect factors of RMI course numbers. In order to meet the objectives, we adopt paired-samples $T$ test and regression method. In Figure 4 we give a description of research frame.

This research administered on insurance and finance departments of higher education upgraded of technological and vocational education and the school years period are 1986 to 2006 .

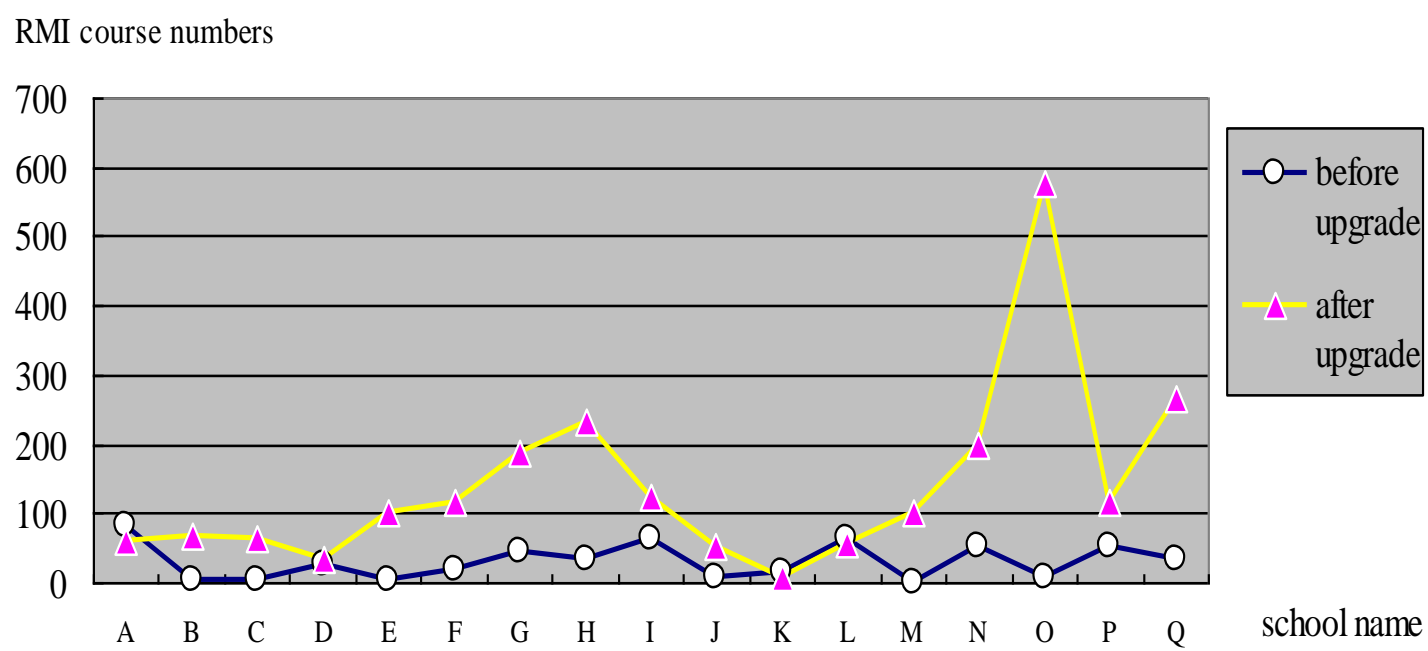

Figure 3 Change in RMI Course Numbers from Junior Colleges Upgraded to Technological Colleges

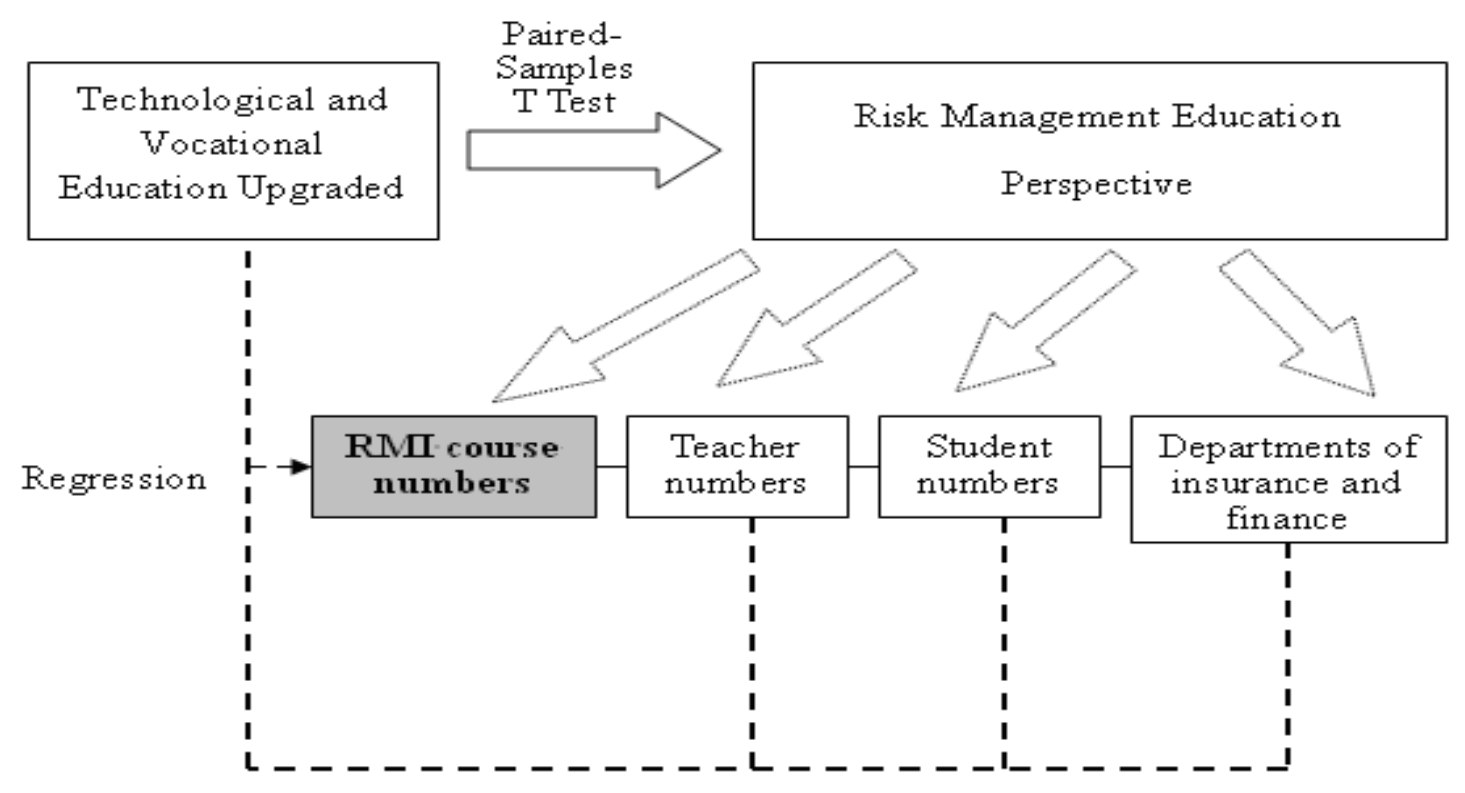

Figure 4 Research of Frame 


\section{Paired-Samples T Test}

To observe differences on RMI course numbers, teacher numbers, student numbers and department of insurance and finance between before upgrade and after upgrade, the hypothesis related to the application of the tests with equations of the general form (1).

$$
\begin{aligned}
& t=\frac{\bar{X}_{1}-\bar{X}_{2}}{\sqrt{\frac{S^{2}{ }_{x 1}+S_{x 2}^{2}-2 r S_{x 1} S_{x 2}}{N}}}, d f=N-1 \\
& H_{0}: u_{1}-u_{2}=0 \\
& H_{1}: u_{1}-u_{2} \neq 0
\end{aligned}
$$

\section{Liner Multiple regression Model}

This research applying regression method, the effects from junior college upgraded to technological college issues are empirically analyze to investigate the factors that influence number of courses. The Taiwan's upgraded schools with environment of the area of risk management is empirically analyzes to investigate the effects that influence courses. A general form of liner multiple regression as form (2).

$$
\begin{aligned}
& \mathrm{Y}_{i}=\beta_{0}+\beta_{1} \mathrm{X}_{i 1}+\beta_{2} \mathrm{X}_{i 2}+\cdots \cdots+\beta_{k} \mathrm{X}_{i k}+\varepsilon_{i} \\
& \quad \varepsilon_{i} \sim \mathrm{N}\left(0, \sigma^{2}\right) \quad \text { and } i=1,2, \ldots, n
\end{aligned}
$$

Currently, the administrative boundaries have 17 upgrade higher school of technological and vocational with finance and insurance department in Taiwan. Empirical model in this paper focuses on multiple regression model as form (3).

$$
\begin{aligned}
& \mathrm{Y}_{i}=\beta_{0}+\beta_{1} \mathrm{X}_{1}+\beta_{2} \mathrm{X}_{2}+\beta_{3} \mathrm{X}_{3}+\beta_{4} \mathrm{X}_{4}+\varepsilon_{i} \\
& \quad \varepsilon_{i} \sim \mathrm{N}\left(0, \sigma^{2}\right)
\end{aligned}
$$

Where $\mathrm{Yi}$ is denotes a dependent variable of RMI course number and $\mathrm{X} 1, \mathrm{X} 2$, $\mathrm{X} 3, \mathrm{X} 4$ denote independent variables of upgrade, insurance and finance department numbers, student numbers and teacher numbers respectively. 
The hypothesis related to the application of the tests with equations of the general form (4), and some variables have been in-transformed as form (4).

$$
\ln (\mathrm{RMICN})=\beta_{0}+\beta_{1}(\mathrm{UP})+\beta_{2}(\mathrm{IFDN})+\beta_{3} \ln (\mathrm{SN})+\beta_{4}(\mathrm{TN})+\varepsilon_{i}
$$

Independent variables "UP" is a dummy variable, use $(0,1)$ to code values of the variable. $\mathrm{UP}=0$, before upgrade and $\mathrm{UP}=1$, otherwise.

$$
\begin{aligned}
& H_{0}: \beta_{1}=\beta_{2}=\beta_{3}=\beta_{4}=0 \\
& H_{1}: H_{0} \text { is not true }
\end{aligned}
$$

\section{EMPIRICAL RESULTS}

We will now use the paired-samples $T$ test result to calculate the value of $t$ test for that upgraded implications relate with the numbers of teacher, RMI course, student and department of insurance and finance. From tables 2 we have seen following three empirical results:

1. The results indicate that these variables included in paired-samples $T$ test result. In the level of significance 0.1 , the student number was not significantly, and the RMI course numbers, departments and teacher numbers were significantly different after upgraded.

2. The decrease of student numbers isn't significance when junior colleges upgraded to technological colleges.

3. The increase of the RMI course numbers, departments and teacher numbers were significant when junior colleges upgraded to technological colleges.

Table 2 Paired-Samples T test result

\begin{tabular}{lcccc}
\hline \multirow{2}{*}{ Variables } & \multicolumn{2}{c}{ Average } & \multirow{2}{*}{ t test } & P-value \\
\cline { 2 - 3 } & Before & After & & \\
\hline RMI course numbers & 30 & 139 & -3.251 & $0.005^{* * *}$ \\
\hline $\begin{array}{l}\text { Department of insurance and } \\
\text { finance }\end{array}$ & 1 & 2 & -4.657 & $0.000^{* * *}$ \\
\hline teacher numbers & 270 & 383 & -1.995 & $0.063^{* *}$ \\
\hline student numbers & 7212 & 5632 & 1.258 & 0.226 \\
\hline
\end{tabular}

\footnotetext{
${ }^{* * * *}$ Significant at 0.01 level

${ }^{* * *}$ Significant at 0.05 level
} 
In Table 3, the p-value of ANOVA table of the regression model is significant that the regression equation can explain variation of RMI courses. $\mathrm{R}$ square and adjusted $\mathrm{R}$ square is 0.735 and 0.698 respectively.

Table 3 ANOVA Table

\begin{tabular}{ccccccc}
\hline Model & & Sum of Squares & df & Mean Square & F & Sig. \\
\hline \multirow{2}{*}{1} & Regression & 47.903 & 4 & 11.976 & 20.094 & $.000(\mathrm{a})$ \\
\cline { 2 - 7 } & Residual & 17.284 & 29 & .596 & & \\
\cline { 2 - 7 } & Total & 65.187 & 33 & & & \\
\hline
\end{tabular}

a Predictors : (Constant)

UP : upgrade

LSN : ln (student numbers)

LTN : ln (teacher umbers)

IFDN : insurance and finance department numbers

b Dependent Variable : LRMICN : $\ln$ (RMI course numbers)

The empirical analysis reported in Table 4. This empirical result finds the coefficient of teacher numbers is negative related to the RMI course numbers. The other coefficients of independent variables are positive $(1.378,0.417,1.441)$, that is student numbers, insurance and finance department and dummy variable "UP" are positive related to the RMI course numbers. Independent variables (UP, IFDN, LSN, LTN) is substantial and significant in the regression model. Higher education of risk management and insurance upgraded to make RMI course diversification to promote the competition of higher education of technological and vocational schools. The paired-samples $\mathrm{T}$ test value of insurance and finance department numbers is negative, that is mean insurance and finance department numbers of upgrade from junior to technological colleges increase. As the department number increased, student number increased. In order to meet environment change needs in a competitive global economy, upgrade from junior to technological colleges offer more RMI courses.

Table 4 presents the results from estimating the four effect factors on RMI course numbers using regression method. Higher education of technological and vocational school upgrade, insurance and finance department numbers, student numbers and teacher numbers had been effected on RMI course numbers in Taiwan. The empirical analysis shows that higher education upgrade is an influential factor on RMI course numbers. We find that upgrade factors have more effect and explain reliability on the 
change of RMI course numbers.

Table 4 Regression Results, Dependent Variable

\begin{tabular}{ccc}
\hline & Dependent Variable: LRMICN & \\
\hline Explanatory Variable & Coefficient & Sig. \\
\hline constant & -6.473 & $0.005^{* * *}$ \\
\hline UP & 1.378 & $0.004^{* * *}$ \\
\hline IFDN & 0.417 & $0.016^{* * *}$ \\
\hline LSN & 1.441 & $0.002^{* * *}$ \\
\hline LTN & -.6751 & $0.048^{* * *}$ \\
\hline
\end{tabular}

${ }^{* * *}$ Significant at 0.05 level

Note : LRMICN : $\ln$ (RMI course numbers)

UP : upgrade

LSN : ln (student numbers)

LTN $: \ln$ (teacher umbers)

IFDN : insurance and finance department numbers

\section{CONCLUSION}

Technological college is the part of higher education, it upgraded rapidly after 1990 to today in Taiwan due to higher educational relevant law published in 1996. Technological college increase extensively because of junior college upgraded to technological college. From the result of paired-samples $T$ test, the decrease of student numbers isn't significance when junior colleges upgraded to technological colleges. The increase of the RMI course numbers, departments and teacher numbers were significant when junior colleges upgraded to technological colleges. The risk management and insurance course affected by junior colleges upgraded to technological colleges, student numbers, teacher numbers, insurance and finance department numbers. This result shows that the higher education RMI courses would respond to the needs of the economy. Quality of risk management and insurance education must arise to meet the need of economy. RMI offers breadth and much-needed integration of business expertise (Gardner and Schmit, 1995). Therefore, the program of risk management and insurance education of junior colleges upgraded to technological colleges are important. We offer the summary results of empirical analysis in Figure 5. Using multiple regression method, the results indicate that these 
variables included in the model, student numbers, teacher numbers, upgrade and department numbers and RMI courses were significantly different. These results also provide that the RMI courses are positively associated with the upgrade, student numbers and department numbers, and negatively related with teacher numbers. Note that the RMI courses have be shared more teachers. However, higher education must meet the need of economy and human resource management, so risk management and insurance courses must take a leading role in upgraded higher education to make technological college more accessible, higher quality service to better meet environment change needs in a competitive global economy.

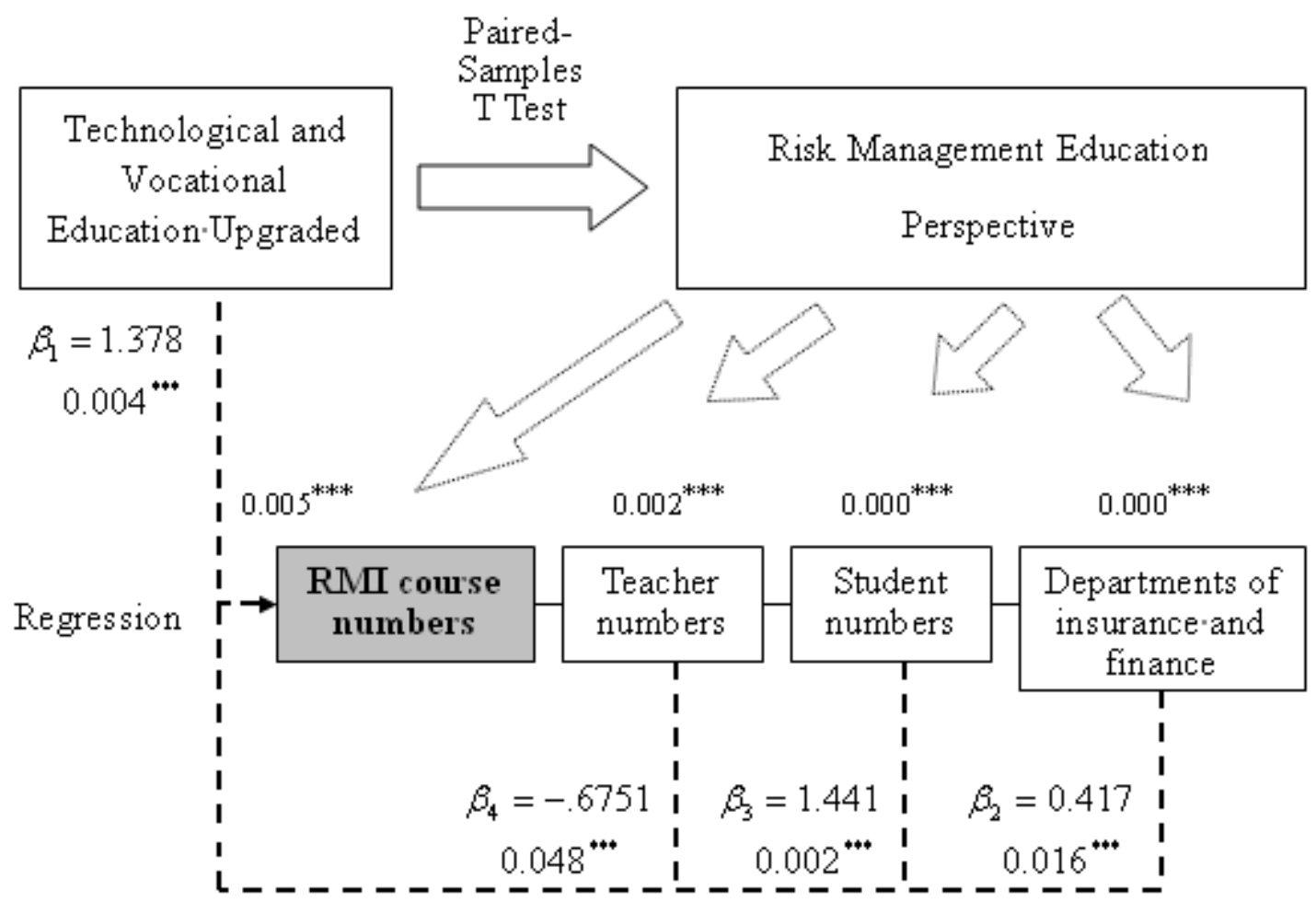

Figure 5 Empirically Analysis Results

\section{ACKNOWLEDGMENTS}

The authors would like to acknowledge the helpful comments of the reviewers.

\section{REFERENCES}

Banks, A. S. (2001). Cross-National time-series data archive [dataset]. Binghamtom, NY: Computer Systems Unlimited.

Barker, B. (1985). Curriccular offerings in small and large high schools: How broad is the disparity. Research in Rural Education, 3(1), 35-38. 
Brown, P. \& Lauder, H. (1996). Education, globalization, and economic development. Journal of Education Policy, 11(1), 1-26.

Cummins, J. D. (1987). Revitalizing risk and insurance education and research. Journal of Risk and Insurance, 54(1), 9-19.

Dorfman, M. (1990). Insurance in the undergraduate curriculum. Journal of Risk and Insurance, 57(1), 47-65.

Doyon, P. (2001). A review of higher education reform in modern Japan. Higher Education, 41(4), 443-470.

Gardner, L. A. \& Schmit, J. T. (1995). Collegiate risk management and insurance education. Journal of Risk and Insurance, 62(4), 625-648.

Gill A. \& Lashine S. (2003). Changes in graduate management education and new business school strategies for the $21^{\text {st }}$ century. Aacademy of Management Learning and Education, 2(3), 233-249.

Huang, G. J. (2000). A prospect in vocational education. Taipei: Normal University Press.

Itoh, A. (2002). Higher education reform in perspective: The Japanese experience. Higher Education, 43(4), 7-25.

Jones, P. W. (1998). Globalization and internationalism: Democratic prospects for world education. Comparative Education, 34(2), 143-155.

Lai, L. H. \& Huang, L. A. (2007). A Studty on the junior college reformed to technological college in Taiwan: The example of relevant department of finance and insurance. EMS Conference 2007, IEEE. Shanghai, China.

Lai, L. H. \& Huang, L. A. (2008). A review of technological and vocational education upgraded in Taiwan based on risk management education perspective. International Conference on Business and Information (BAI) 2008. Seoul, South Korea.

Law, W. W. (1995). The role of the state in higher education reform : Mainland China and Taiwan. Comparative Education Review, 39(3), 322-355.

Law, W. W. (1998). Higher education in Taiwan: the rule of law and democracy. International Higher Education, 11(1), 4-6.

Lin, T. G. \& Chang, S. T. (1998). The trends of vocational education in Taiwan. Journal of Technical and Vocational Education, 43(1), 6-12.

Melnick, S.A. et. al. (1987). School district size, student achievement and high school course offerings in Connecticut. Research in Rural Education, 4(3), 119-123.

Meyer, K., Kamens, D., Benavot, A. M. Cha,Y., \& Wong, S. (1992). School Knowledge for the masses. London: Falmer Press. 
Ministry of Education (MOE) Taiwan. (2007). Education statistics of the Republic of China. Taipei, Taiwan: Ministry of Education (MOE).

Mok, K. H. (2000). Reflecting globalization effects on local policy: Higher education reform in Taiwan. Journal of Educational Policy, 15(6) , 637-660.

Mongkhonvanit, P. \& Emery, S. L. (2003). Asian perspectives on European higher education. Higher Education in Europe, 28(1), 50-56.

Pisut, J. (1993). Higher education reforms in the Slovak Republic. European Journal of Education, 28(4), 421-428.

Schofer, E. \& Meyer, W. (2005). The worldwide expansion of higher education in the twentieth century. American Sociological Review, 70(6), 898-920.

Skipper, Harold D. Jr. (1994). Presidential address: risk management and insurance education: will we miss the boat? The Journal of Risk and Insurance, 61(2), 183-191.

Thrower, E. \& Gardner, L. (1989). Collegiate risk and insurance programs in the United States, 1989-88. Des Moines, Iowa: Insurance Center, Drake University, New York: College of Insurance.

Thrower, E. \& Diana, R. (1989). Insurance education at American colleges and universities. Des Moines, Iowa: Insurance Center.

Wiles, J. W. (1995). Middle level education in rural America. (ERIC Document Reproduction Service No. ED 385426). Charleston, America: ERIC/CRESS.

Yang, C. T. (1995). The important policy in the current vocational education. Journal of Technical and Vocational Education, 28(1), 2-7. 